Original Article

\title{
Effect of biotherapic of Alternaria solani on the early blight of tomato-plant and the in vitro development of the fungus
}

\author{
Solange Monteiro de Toledo Piza Gomes Carneiroํㅡ, Euclides Davidson Bueno \\ Romano $^{1}$, Erika Pignoni ${ }^{1}$, Marcus Zulian Teixeira ${ }^{2}$, Maria Elizabeth da Costa \\ Vasconcelos ${ }^{1}$, José Carlos Gomes ${ }^{1}$
}

(1) Agronomic Institute of Paraná, IAPAR, PR, Brazil

(2) Medicine Faculty, USP, SP, Brazil

\begin{abstract}
Background: homeopathy is a means permitted in organic agriculture to control disease and plagues; biotherapics are a practical means for farmers to intervene on the health of plants in agro-ecological systems of production. Tomato-plants can be affected by several diseases, one of the most significant ones in Brazil is early blight, caused by fungus Alternaria solani, due to the damage it causes and its wide distribution in the country. Aims: to establish whether a biotherapic of $A$. solani may interfere on the in vitro development of the fungus and whether it affects the severity of early blight on tomato-plants in greenhouse. Methods: the effect of the biotherapic on the fungus was evaluated through the percentage of germinated spores under microscope and the growth of colonies in a culture medium. Treatments used were: biotherapic $26 \mathrm{cH}, 27 \mathrm{cH}, 28 \mathrm{cH}, 29 \mathrm{cH}$ and $30 \mathrm{cH}$; sterilized distilled water; and diluted and agitated hydroalcoholic solution. The effect of the biotherapic on the development of disease was evaluated in 4 experiments in greenhouse. Plants were kept in vases and subjected to artificial inoculation of the fungus after the application of treatments. Evaluation of disease was carried out through diagrammatic scale. Results: no treatment affected the germination of spores or the development of fungus colonies in the culture medium. In the first test, treatment $26 \mathrm{cH}$ differed from water in Tukey's test at $5 \%$ but did not differed from diluted and agitated hydroalcoholic solution. In the second test, treatments $27 \mathrm{cH}$ and $28 \mathrm{cH}$ showed significant difference from both water and hydroalcoholic solution with an average control of disease of $57 \%$ and $62 \%$ respectively. The other 2 tests did nor exhibit any significant effect. Conclusions: there was no direct effect of the biotherapic on the fungus, but there was an effect on the severity of the disease. Factors affecting the efficiency of the biotherapic must be better understood before it can be recommended to farmers for the management of early blight in tomato-plants.
\end{abstract}

Keywords: Solanum lycopersicum, Alternaria solani, isotherapy.

\section{Introduction}

Early blight is a disease that significantly affects tomato-plants (Solanum lycopersicum L.) and other plants of family Solanaceae, either in conventional or organic cultivation. Disease is frequent wherever tomato is grown in Brazil, resulting in heavy losses in production [1,2]. Its etiologic agent is fungus Alternaria solani (Ell. \& Martin) Jones \& Grout, which damages the leaves (Figure 1), stalks, stems and fruits, resulting in severe destruction of the aerial part and reduction of the size and number of fruits. 
Plants have mechanisms of resistance to diseases, which are characterized by their dynamic and coordinated nature, whereas their effectiveness depends on the speed and magnitude of their expression. Activation of the latent mechanisms of resistance to disease can be achieved through the use of external agents, such as non pathogenic micro-organisms, inactivated pathogens, mushrooms and plants extracts, among others; this process is known as induced resistance [3].

Homeopathy is one of the means permitted in organic agriculture for the control of diseases and plagues in plants [4], and it can be used to activate the process of induced resistance.

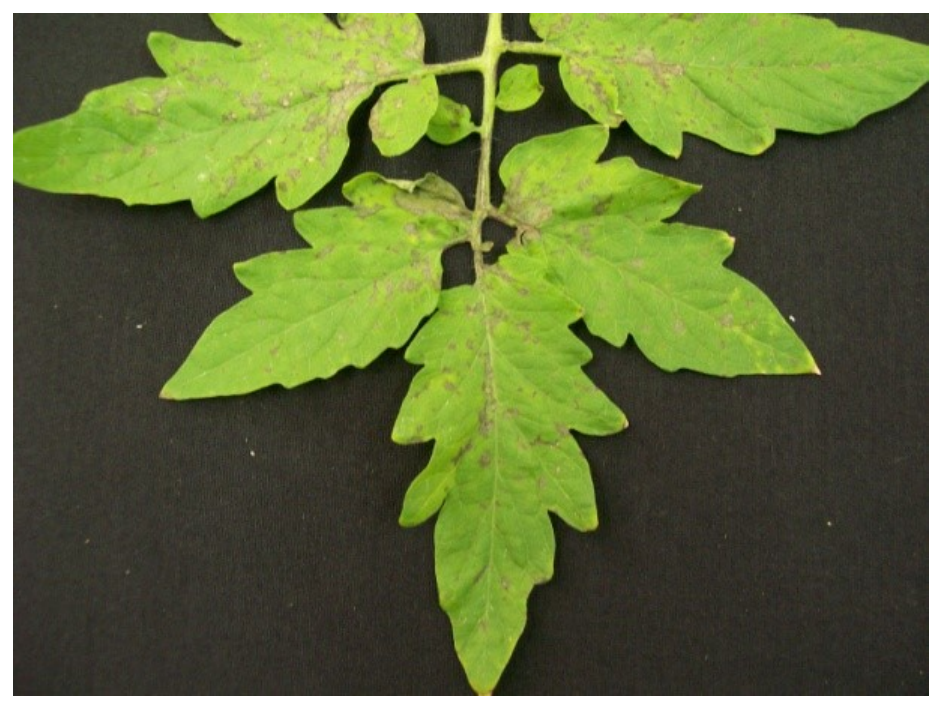

Figure 1: Signs of early blight in tomato-plant leaves

Studies on the effect of homeopathy on plants include the following features: effect of homeopathic medicines on the germination of seeds, growth of seedlings, plants physiology, development of adult plants and productivity; effect of homeopathic medicines on diseased plants and phytopathogenic micro-organisms; use of isotherapy to revert the toxic action of substances; and the control of diseases and plagues. Some reviews evaluating such studies have already been published $[5,6,7]$.

Homeopathy is grounded on the similarity between the symptoms of patients and the symptoms appearing in pathogenetic trials of substances on healthy individuals. On the other hand, isopathy is ruled by the principle of equality. The term "isotherapy" designates treatments carried out by the same substance that causes disease, no matter whether organic or inorganic [8]. Currently, isotherapics, auto-isotherapics and nosodes are subsumed under the category of biotherapics [9]. Some authors have studied the effect of biotherapics on the diseases and plagues of plants. Rossi et al [10] evaluated the efficiency of biotherapic of Xanthomonas vesicatoria on the control of tomato-plant bacterial spot. They observed a reduction in the severity of disease when treatments were irrigated, whereas sprayed treatments did not control the disease. Fazolin et al [11] observed the effect of a biotherapic in the reduction of the consumption of the foliage area by Cerotoma tingomarianus. Diniz et al [12] did not observe any effect of a biotherapic prepared from diseased tomatoplant leaves in the control of late blight.

Once their efficiency is proven, biotherapics will become a practical means to manage disequilibria in plants in organic and/or agro-ecological cultures. The aim of this study was to assess whether a biotherapic of $A$. solani had an effect on the severity of tomato-plant early blight in greenhouse and whether it affects the in vitro development of the fungus.

\section{Materials e methods}

\section{Obtaining of plants and fungus, production of biotherapic and preparation of treatments}

The variety which was utilized in the experiments was 'Santa Clara Miss Brazil'. The seeds were acquired in shops in Londrina, Paraná, Brazil. Seeds were sown in a substrate containing a mixture of earth, sand and farmyard dung in proportion 3:1:1.5. When plants had grown 6 leaves, in vegetative development, before flowering, they were used in the experiments. 
An isolate of $A$. solani was obtained from tomato-plants picked in the north of Paraná exhibiting signs of early blight. Isolation was carried out in a culture medium made of V8 juice ( $34 \mathrm{~g}$. agar; $5.1 \mathrm{~g}$ calcium carbonate; 15 $\mathrm{ml}$ acetone; $340 \mathrm{ml}$ vegetable juice-V8; $1,360 \mathrm{ml}$ distilled water) incubated in germination chamber at $24^{\circ} \mathrm{C}$ for about 7 days. The pure isolate was kept in test-tubes containing the same culture medium, and after the colonies grew, they were stored in a fridge.

To prepare the biotherapic, a small part of the fungus colony was transferred to a Petri dish containing V8 medium and incubated in germination chamber at $24^{\circ} \mathrm{C}$ in the dark for 14 days. Fungal structures were scraped from the culture medium and the biotherapic was prepared through trituration in lactose [13].

The biotherapic was tested in dilutions $26 \mathrm{cH}$ to $30 \mathrm{cH}$ prepared according to Brazilian Homeopathic Pharmacopoeia [13]. These dilutions were chosen on the grounds of preliminary results indicating that tomato-plants responded to some of these dilutions. Two controls were used: one was simple water and the other, diluted and agitated hydroalcoholic solution equivalent to $26 \mathrm{cH}$, prepared through the dilution in water of a $23 \mathrm{cH}$ (kept in alcohol 70\%). Thus, all diluted and agitated samples (controls and biotherapics, except water) contained $0,00007 \%$ of alcohol. Water for tests was distilled and sterilized and sucussions were made manually, beating 100 times the bottom of the flask against a semi-rigid surface with continuous and rhythmic motions.

\section{Effect on the germination of conidia and mycelial growth of A. solani}

A $25 \mu \mathrm{l}$ aliquot of a suspension of spores in concentration $2 \times 10^{4}$ conidia/ml was placed with a pipette on one end a slightly burned slide for microscopy. Then, $25 \mu \mathrm{l}$ of treatment were added forming a $50 \mu \mathrm{l}$ drop. Each slide received 2 drops (2 repetitions) prepared in this manner and was incubated in gerbox with 2 sheets of filter paper moistened with sterilized distilled water until the emergence of the germ tubes of the spores. For each treatment 4 repetitions were made. The gerbox was kept in germination chamber for 5 hours in the dark constantly at $24^{\circ} \mathrm{C}$

Then, evaluation was carried out through optic microscopy, counting the first 50 conidia found in each drop and recording the number of both germinated and non germinated conidia.

In order to assess the effect of treatments on the mycelia growth of the fungus, 7 Erlenmeyer flasks were prepared with $90 \mathrm{ml} \mathrm{V8} \mathrm{culture} \mathrm{medium} \mathrm{in} \mathrm{each} \mathrm{one.} \mathrm{After} \mathrm{sterilization} \mathrm{of} \mathrm{the} \mathrm{culture} \mathrm{medium,} \mathrm{each}$ Erlenmeyer flask was cooled and before the medium solidified, it was added $10 \mathrm{ml}$ of the corresponding treatment, pouring immediately the medium in Petri dishes. After solidification of the medium, a $7 \mathrm{~mm}$ diameter disk of mycelium of $A$. solani was replated at the center of each Petri dish. Dishes were kept in incubator for 7 days at $24^{\circ} \mathrm{C}$ in the dark. Then, 2 readings were made in perpendicular of the diameter of the fungus colony in the dish. Treatments used in in vitro tests were $26 \mathrm{cH}, 27 \mathrm{cH}, 28, \mathrm{cH}, 29, \mathrm{cH}, 30 \mathrm{cH}$, diluted and agitated hydroalcoholic solution and water.

\section{Effect of the biotherapic on the severity of tomato-plant early blight}

All 4 tests were carried out in greenhouse at the experimental station of Instituto Agronômico do Paraná IAPAR, at Londrina, Paraná, Brazil. The specific conditions of each test are described in Table 1.

Table 1: description of treatments, number of repetitions, period of treatment, number and mode of application of treatments 


\begin{tabular}{c|l|c|c|l}
\hline Test $^{\mathbf{o}}$ & \multicolumn{1}{|c|}{ Treatments $^{\mathbf{a}}$} & $\begin{array}{c}\mathbf{N}^{\mathbf{o}} \text { of } \\
\text { repetitions }\end{array}$ & $\begin{array}{c}\text { Days of } \\
\text { treatment }\end{array}$ & Mode of application \\
\hline 01 & $26 \mathrm{cH}, 28 \mathrm{cH}, 30 \mathrm{cH} \mathbf{b}$ & 06 & 09 & Sprayed 2 times/day \\
\hline 02 & $26 \mathrm{cH}, 27 \mathrm{cH}, 28 \mathrm{cH}, 29 \mathrm{cH}, 30 \mathrm{cH}$ & 20 & 10 & $\begin{array}{l}\text { Sprayed } 2 \text { times/day } \\
\text { and } 40 \mathrm{ml} \text { in the soil 2 } \\
\text { times/day }\end{array}$ \\
\hline 03 & $26 \mathrm{cH}, 27 \mathrm{cH}, 28 \mathrm{cH}, 29 \mathrm{cH}, 30 \mathrm{cH}$ & 10 & 10 & $\begin{array}{l}\text { Sprayed 2 times/day } \\
\text { and 40 ml in the soil 2 } \\
\text { times/day }\end{array}$ \\
\hline 04 & $26 \mathrm{cH}, 27 \mathrm{cH}, 28 \mathrm{cH}, 29 \mathrm{cH}, 30 \mathrm{cH}$ & 12 & 10 & Sprayed once a day \\
\hline
\end{tabular}

a In all experiments controls "water" and "hydroalcoholic solution" were used.

b Treatments $27 \mathrm{cH}$ and $29 \mathrm{cH}$ were not included.

The following conditions were applied to all tests. The experimental design was fully randomized and each repetition consisted of a vase with 1 plant. Controls used were water and diluted and agitated hydroalcoholic solution as explained above. Treatments were sprayed directly on the leaves through new manual sprays; for each treatment a different device was used. Vases were transferred outside the greenhouse to be sprayed; spraying continued until leaves were completely wet and before fluid started to run down. When treatments were applied through spraying of the aerial part and irrigation of the soil, both treatments were carried out at the same time.

When the period of treatment ended, which lasted 9 or 10 according to the test, plants were inoculated with a suspension of spores of $A$. solani in concentration $1.2 \times 10^{4}$ conidia/ml. After inoculation, plants were kept in a acclimatized room for 24 hours at $21^{\circ} \mathrm{C}$ and photoperiod 12 hours dark and 12 hours light. Then, plants were transferred to the greenhouse where they remained until the end of the study.

The severity of early blight was assessed about 6 days after inoculation through diagrammatic scale [14], estimating visually on the leaves of each plant, the percentage of leaf area covered with signs of the disease. Data were transformed in $\sqrt{x+0.5}$ for variance analysis, carried out with software SAS; comparison of means was made using Tukey's test at $5 \%$ probability.

\section{Results}

There was no effect of treatments on the germination of spores of $A$. solani according to F-test of variance analysis. There was not either alteration in the germination tubes or in the shape of the spores in any of the treatments. The growth of colonies in V8 medium, either pure or with the addition of treatments was not either affected, as it neither was affected their color and general appearance.

The tests with tomato-plants in vegetation-house gave variable results. In test no. 1 , only treatment $26 \mathrm{cH}$ differed from water according Tukey's test at 5\% (Table 2), but it did not differed from the hydroalcoholic control or the remainder of treatments. Compared with water, biotherapic $26 \mathrm{cH}$ decreased the severity of disease $72.8 \%$. In the second test, treatments $26 \mathrm{cH}, 27 \mathrm{cH}$ and $28 \mathrm{cH}$ differed significantly from water and decreased the severity of disease $36 \%, 61 \%$ and $66 \%$, respectively. However, only treatments $27 \mathrm{cH}$ and $28 \mathrm{cH}$ differed significantly from the hydroalcoholic control. No treatment in tests no. 3 and 4 differed significantly from water. (Table 2). 
Table 2: Effect of biotherapic of $A$. solani on the severity of early blight

\begin{tabular}{|c|c|c|c|c|}
\hline \multirow[b]{2}{*}{ Treatments } & \multicolumn{3}{|c|}{ Severity (\%) } & \multirow[b]{2}{*}{$4^{\text {th }}$ test } \\
\hline & $1^{\text {st }}$ test & $2^{\text {nd }}$ test & $3^{\text {rd }}$ test & \\
\hline Water & $28,4 \mathrm{a}^{1}$ & $79,1 \mathrm{a}$ & $64,7 \mathrm{a}$ & $21,3 \mathrm{a}$ \\
\hline Hydroalcoholic control & $14,4 \mathrm{ab}$ & $62,1 \mathrm{ab}$ & $66,2 \mathrm{a}$ & $23,1 \mathrm{a}$ \\
\hline Alternaria solani $26 \mathrm{cH}$ & $7,7 \quad b$ & $49,9 \quad \mathrm{~b}$ & $60,2 \mathrm{a}$ & $15,6 \mathrm{a}$ \\
\hline Alternaria solani $27 \mathrm{cH}$ & - & 30,1 & $60,6 \mathrm{a}$ & $13,8 \mathrm{a}$ \\
\hline Alternaria solani $28 \mathrm{cH}$ & $16,2 \mathrm{ab}$ & 26,8 & $58,4 \mathrm{a}$ & $18,0 \mathrm{a}$ \\
\hline Alternaria solani $29 \mathrm{cH}$ & - & $72,3 \mathrm{ab}$ & $63,2 \mathrm{a}$ & $17,0 \mathrm{a}$ \\
\hline Alternaria solani $30 \mathrm{cH}$ & $20,7 \mathrm{ab}$ & $63,2 \mathrm{ab}$ & $68,4 \mathrm{a}$ & $19,6 \mathrm{a}$ \\
\hline C.V. & $27,0 \%$ & $26,1 \%$ & $14,0 \%$ & $30,1 \%$ \\
\hline
\end{tabular}

${ }^{1}$ Means followed by different letters differ one from the others Tukey's test at $5 \%$.

\section{Discussion}

Homeopathic medicines can affect the development of phytopathogenic fungi. Rivas et al [15] observed that homeopathic remedies reduced the percentage of germination of conidia of $A$. solani, and germination was completely abolished with Selenium 31cH. Kumar \& Kumar [16] reported that Alternaria alternata showed $100 \%$ inhibition of germination with Spigelia. In the present study, there was no effect of the biotherapic on the germination of spores and the growth of $A$. solani colonies. This indicates that the decrease in the severity of disease observed with some treatments was not due to a direct action on the fungus but probably to the induction of resistance in the host. Biochemical analyses are needed to confirm this hypothesis. Two among the characteristics of induced resistance are the absence of toxic effect of the inducer on the pathogenic agent and dependence on the environment and genotype of the plant. Thus, the fact that there was no direct effect of the biotherapic on the fungus suggests that this might have been the mechanism implied in the first 2 tests.

Differences in the efficacy of treatments $26 \mathrm{cH}, 27 \mathrm{cH}$ and $28 \mathrm{cH}$ among tests may be due to factors such as number and mode of application of the biotherapic, as well as the duration of treatment. On the other hand, the variation in the results can be due to the complexity itself of the observed stimulus-response relation in tests with high dilutions [17]; the repeatability of this type of studies has been already discussed by some authors [17-19]. Few published studies of homeopathy and isotherapy in plants present more than one test, a fact that does not allow establishing whether this is a common occurrence. On the other hand, alterations after a given treatment due to factors other, such as quality of seeds, for instance, have already been reported [20].

The mode of application of treatments to plants needs to be better studied. In this study, the association of irrigation of the soil and spraying of plants seemed to be the most efficient mode of application. Rossi et al [10] observed that the biotherapic of $X$. vesicatoria was efficient to reduce the severity of disease when applied through irrigation, but it showed no effect when sprayed. It is important that future studies investigate more extensively the irrigation of plants with the tested treatments. 
The fact that biotherapic $26 \mathrm{cH}$ did not differed from the diluted and agitated control indicates the need to evaluate in future studies a smaller number of treatments and include the diluted and agitated control of each one. A larger number of repetitions is also recommended, since the best significances were seen in the $2^{\text {nd }}$ test, which had 20 repetitions. Furthermore, it is important that future studies standardize other factors, such as the batch of seeds and the mode of application of treatments.

\section{Conclusions}

There was no direct effect of the biotherapic on the fungus, but it was observed an effect on the severity of disease. The factors affecting the efficiency of the biotherapic need to be better understood before it can be recommended to farmers for the control of early blight in tomato-plants.

\section{Acknowledgment}

To Amarilys de Toledo César, $\mathrm{PhD}$, for the preparation of the biotherapic.

\section{References}

[1] Kurozawa C, Pavan MA. Doenças do tomateiro. In: Kimati H., Amorim L, Rezende JAM, Bergamin Filho A, Camargo LEA, editors. Manual de Fitopatologia: doenças das plantas cultivadas. São Paulo(Brazil): Editora Agronômica Ceres; 2005. p.607-626. [portuguese].

[2] Darolt MR. As dimensões da sustentabilidade: Um estudo da agricultura orgânica na região metropolitana de Curitiba, Paraná [dissertation]. Curitiba: Universidade Federal do Paraná; 2000. [portuguese].

[3] Stadnik MJ, Maraschin M. Indução de resistência de plantas a fitopatógenos. In: Stadnik MJ, Talamini V. Manejo ecológico de doenças de plantas. Florianópolis (Brazil): CCA/UFSC, 2004. p.221-244.

[4] Brasil, Ministério da Agricultura, Pecuária e Abastecimento. Instrução Normativa $\mathrm{n}^{0}$ 64, de 18 de dezembro de 2008, Diário Oficial da União, $\mathrm{n}^{\circ}$ 247, de 19 de dezembro de 2008. disponível em: http://www.agricultura.gov.br/pls/portal/docs/page/mapa/legislacao/publicacoes_dou/publicacoes_dou_2008/pub licacoes_dou_dezembro_2008/do1_2008_12_19-mapa_0.pdf

[5] Betti L, Trebbi G, Nani D, Majewsky V, Scherr C, Jäger T, Baumgartner S. Models with plants, microorganisms and viruses for basic research in homeopathy. In: Bonamin LV, editor. Signals and images: contributions and contradictions about high dilution research. New York (USA): Springer; 2008. p.97-112.

[6] Majewsky V, Arlt S, Shah D, Scherr C, Jäger T, Betti L, Trebbi G, Bonamin L, Klocke P, Baumgartner S. Use of homeopathic preparations in experimental studies with healthy plants. Homeopathy. 2009; 98: 228243.

[7] Betti L, Trebbi G, Majewsky V, Scherr C, Shah-Rossi D, Jäger T, Baumgartner S. Use of homeopathic preparations in phytopathological models and in field trials: a critical review. Homeopathy. 2009; 98:244-266.

[8] Kossak-Romanac, A. Homeopatia em 1000 conceitos. $3^{\text {a }}$ ed., editora Elcid, São Paulo, 2003. [portuguese]. 
[9] Amorim VO, Fontes OL. Bioterápicos. In: Fontes OL. Farmácia Homeopática: teoria e prática. São Paulo: Editora Manole; 2009. p.212-229. [portuguese].

[10] Rossi F, Melo PCT, Pascholati SF, Casali VWD, Ambrosano EJ, Guirado N, Mendes PCD, Ambrosano GMB, Schammass EA, Toffano L, Di Piero RM. Aplicação de Bioterápico visando induzir resistência em Tomateiro contra Mancha Bacteriana. Revista Brasileira de Agroecologia. 2007; 2 (1): 858-861. [portuguese].

[11] Fazolin M, Estrela JLV, Argolo VM. A utilização de medicamentos homeopáticos no controle de Cerotoma tingomarianus Bechyné (Colioptera, Chaysomelidae) em Rio Branco, Acre. Pesquisa Homeopática. 1997; 12(1): 50-59. [portuguese].

[12] Diniz, LP, Maffia LA, Dhingra OD, Casali VWD, Santos RHS, Mizubuti ESG. Avaliação de produtos alternativos para controle da requeima do tomateiro. Fitopatologia Brasileira. 2006; 31(2): 171-179. [portuguese].

[13] Farmacopéia homeopática brasileira. 2th ed. São Paulo (Brazil): Atheneu; 1997. [portuguese].

[14] Boff P. Epidemiologia e controle químico da Mancha-de-Estenfílio (Stemphylium solani Weber) e da Pinta-Preta (Alternaria solani (Ellis \& Martin) Jones\&Grout) em dois sistemas de condução do tomateiro (Lycopersicon esculentum Mill.). [dissertation]. Viçosa (Brasil): Universidade Federal de Viçosa; 1988. [portuguese].

[15] Rivas, E.; Ceceña, C.; Guajardo, G. Acción de fármacos homeopaticos sobre la germinación conidial de Alternaria solani y semilla de trigo. Boletín Mexicano de Homeopatia. 1996; 29(2):44-46. [spanish].

[16] Kumar R, Kumar S. Effect for certain homoeopathic medicines on fungal growth and conidial germination. Indian Phytopathology. 1980; 33: 620-621.

[17] Bellavite P, Signorini A. The emerging science of homeopathy: complexity, biodynamics, and nanopharmacology. 2nd ed. Berkeley: North Atlantic Books; 2002.

[18] Endler PC, Thieves K, Reich C, Matthiessen P, Bonamin L, Scherr C, Baumgartner S. Repetitions of fundamental research models homeopathically prepared dilutions beyond 10-23: a bibliometric study. Homeopathy. 2009; 99: 25-36.

[19] Baumgartner S. Reproduction and reproductibility in homeopathy: Dogma or Tool? The Journal of Alternative and Complementary Medicine. 2005; 11(5): 771-772.

[20] Baumgartner S, Shah D, Schaller J, Kämpfer U, Thurneysen A, Heusser P. Reproducibility of dwarf pea shoot growth stimulation by homeopathic potencies of gibberellic acid. Complementary Therapies in Medicine. 2008; 16: 183-191.

\section{Efeito do bioterápico de Alternaria solani na pinta-preta em tomateiros e no desenvolvimento in vitro de fungos}

\section{RESUMO}

Introdução: a homeopatia é um recurso permitido na agricultura orgânica, para o controle de doenças e pragas; bioterápicos constituem numa maneira prática para produtores intervirem na saúde de plantes, em 
sistemas de produção agro-ecológico. Plantas de tomate podem ser afetadas por várias doenças. A pinta-preta, causada pelo fungo Alternaria solani, é uma das mais críticas no Brasil, atingindo várias regiões do país. Objetivos: verificar se o bioterápico $A$. solani pode interferer no desenvolvimento in vitro do fungo e se afeta a severidade da pinta-preta em plantas de tomates produzidas em estufa. Metodos: o efeito do bioterápico sobre o fungo foi avaliado através da porcentagem de esporos germinados, observados por microscopia e pelo crescimento de colônias em meio de cultura. Os tratamentos usados foram: bioterápico $26 \mathrm{cH}, 27 \mathrm{cH}, 28 \mathrm{cH}$, $29 \mathrm{cH}$ e $30 \mathrm{cH}$; água deslitada esterelizada; solução hidroalcoólica diluída e agitada. O efeito do bioterápico no desenvolvimento da doença foi avaliado em 4 experimentos realizados em estufa. As plantas foram mantidas em vasos e submetidas à inoculação artificial do fungo, após a aplicação dos tratamentos. A doença foi avaliada usando-se escalas diagramáticas. Resultados: nenhum tratamento afetou a germinação de esporos ou o desenvolvimento de colônias de fungos, em meio de cultura. No primeiro experimento, o tratamento $26 \mathrm{cH}$ diferiu da água (teste de Tukey a 5\%) mas não da solução hidroalcoólica diluída e agitada. No segundo, os tratamentos $27 \mathrm{cH}$ e $28 \mathrm{cH}$ apresentam diferenças significativas tanto em relação à água quanto à solução hidroalcoólica, com um controle da doença da ordem de 57\% e $62 \%$ respectamente. Os outros 2 experimentos não apresentaram efeitos significativos. Conclusões: não há efeito direto do bioterápico no fungo, porém existe diferença na severidade da doença. Os fatores que afetam a eficiência do bioterápico devem ser melhor entendidos, antes de que sejam recomendados aos produtores, para o controle da pinta-preta em tomateiros.

Palavras-Chave: Solanum lycopersicum, Alternaria solani, isoterapia.

\title{
Efecto del bioterápico de Alternaria solani e el tizón temprano del tomate y desarrollo in vitro del hongo
}

\begin{abstract}
RESUMEN
Justificación: la homeopatía es un recurso autorizado en la agricultura orgánica para controlar enfermedades e plagas; los bioterápicos son un medio útil para los cultivadores de intervenir en la salud de las plantas en sistemas agro-ecológicos de producción. Las plantas de tomate pueden ser afectadas por varias enfermedades, una de las más importantes entre ellas en Brasil es el tizón temprano, causado por el hongo Alternaria solani, debido al daño que causa y a su amplia distribución en el país. Objetivos: determinar si un bioterápico de A. solani puede interferir en el crecimiento in vitro del hongo y si afecta la severidad del tizón temprano en plantas de tomate en invernadero. Métodos: el efecto del bioterápico sobre el hongo fue evaluado mediante el porcentaje de esporas germinadas al microscopio y el crecimiento de colonias en un medio de cultivo. Los tratamientos utilizados fueron bioterápico $26 \mathrm{cH} \ldots$ y $30 \mathrm{cH}$; agua destilada esterilizada y solución hidroalcohólica diluia y agitada. El efecto del bioterápico sobre el desarrollo de la enfermedad fue evaluado en 4 experimentos en invernadero. Las plantas fueron conservadas en macetas e sometidas a inoculación artificial del hongo después de la aplicación de los tratamientos. La evaluación de la enfermedad fue realizada mediante escala diagramática. Resultados: ningún tratamiento afectó la germinación de las esporas ni el crecimiento de las colonias del hongo en el medio de cultivo. En el primer experimento, el tratamiento $26 \mathrm{cH}$ presentó diferencia significativa respecto al agua, según el test de Tukey con $5 \%$ de probabilidad, pero no presentó diferencia significativa con la solución hidroalcohólica diluida y agitada. En el segundo experimento, los tratamientos $27 \mathrm{cH}$ y $28 \mathrm{cH}$ mostraron diferencia significativa con ambos, agua y solución hidroalcohólica, con un control promedio de la enfermedad de $57 \%$ y $62 \%$, respectivamente. Los otros 2 experimentos no mostraron ningún resultado significativo. Conclusión: no hubo efecto directo del bioterápico sobre el hongo, pero hubo efecto sobre la severidad de la enfermedad. Los factores que afectan la eficiencia del bioterápico deben ser mejor comprendidos antes que pueda ser recomendado a los cultivadores en el manejo del tizón temprano del tomate.
\end{abstract}

Palabras-Clave: Solanum lycopersicum, Alternaria solani, isoterapia.

\section{(c) BY-NC-ND Licensed to GIRI}

Support: authors declare that this study received no funding

Conflict of interest: authors declare there is no conflict of interest

Received: 02 August 2010; Revised: 13 December 2010; Published: 20 December 2010.

Correspondence author: Solange Monteiro de Toledo Piza Gomes Carneiro, solange_carneiro@iapar.br.

How to cite this article: Carneiro SMTPG, Romano EDB, Pignoni E, Teixeira MZ, Vasconcelos MEC, Gomes JC. Effect of biotherapic of Alternaria solani on the early blight of tomato-plant and the in vitro development of the fungus. Int $J$ High 
Int J High Dilution Res 2010; 9(33): 147-155

Dilution Res [online]. 2010 [cited YYYY Month dd]; 9(33):147-155. Available from: http://www.feg.unesp.br/ ojs/index.php/ijhdr/article/view/410/451 